\title{
Ring chromosome 8 syndrome
}

INSERM

\section{Source}

INSERM. (1999). Orphanet: an online rare disease and orphan drug data base. Ring chromosome 8 syndrome. ORPHA:1450

Chromosome 8-derived supernumerary ring/marker is a rare chromosomal anomaly comprising variable parts of chromosome 8. The phenotype of mosaic or non-mosaic supernumerary $\mathrm{r}(8) / \operatorname{mar}(8)$ ranges from almost normal to variable degrees of minor abnormalities, and growth and mental retardation overlapping with the well-known mosaic trisomy 8 syndrome (see this term). 